Kadar Glukosa Darah Sewaktu pada Pasien PROLANIS Trimester I dan Trimester II

\title{
Blood Glucose Levels in Trimester I And II Trimester PROLANIS Patients
}

\section{MAHARDIKA PUTRI SINTYA DEWI}

\author{
UPTD Puskesmas Karangpucung II \\ Jl. Raya Surusunda No 17, Kec. Karangpucung, Kab.Cilacap, Jawa Tengah \\ Email: mahardikaputrisintyadewi@gmail.com
}

\begin{abstract}
Abstrak
Parameter pemeriksaan kadar glukosa merupakan pemriksaan yang dilakukan untuk penderita Diabetes Mellitus (DM) sebagai penegak diagnosis, monitoring, terapi, dan timbulnya komplikasi, sehingga terjadinya perkembangan penyakit dapat dimonitor dengan baik. Pemeriksaan kadar glukosa darah sewaktu dapat mungukur kadar glukosa darah tanpa mengukur waktu makan terakhir. Puskesmas mempunyai Program Pengendalian Penyakit Kronis (PROLANIS) yang bertujuan untuk mendorong peserta penyandang penyakit kronis mencapai kualitas hidup yang optimal. PROLANIS diadakan setiap bulan dengan memberikan obat dan melakukan pemeriksaan glukosa darah sewaktu, pada pasien prolanis trimester I kadar gula tinggi seharusnya pada trimester II akan menurun. Tujuan Penelitian mengetahui gambaran kadar glukosa darah sewaktu pada pasien prolanis trimester I dan trimester II di Puskesmas Wangon II Banyumas Tahun 2019. Metode Penelitian penelitian ini merupakan penelitian observasional dengan kriteria penelitian deskriptif dengan sampel semua pasien PROLANIS yang melakukan pemeriksaan kadar glukosa darah. Hasil Penelitian subyek penelitian adalah pasien PROLANIS sejumlah 45 orang yang di periksa kadar glukosa darah sewaktunya. Hasil penelitian menunjukan bahwa 6 orang pasien berjenis kelamin laki-laki $(41,31 \%)$ dan 39 orang pasien berjenis kelamin perempuan $(58,69 \%)$ Kesimpulan penelitian ini menunjukan hasil kadar glukosa pada pasien PROLANIS berjenis kelamin laki-laki tertinggi pada trimester I adalah 901 dan trimester II adalah 657, pada kadar glukosa darah perempuan tertinggi pada trimester I adalah 1372 dan trimester II 841. Kepatuhan pengobatan ini tetap menjadi tolak ukur utama dalam proses perubahan kadar glukosa darah.
\end{abstract}

Kata Kunci : Glukosa Darah Sewaktu ; Prolanis ; Trimester I dan Trimester II

\begin{abstract}
Blood glucose level checks are generally carried out for people with Diabetes Mellitus (DM) to establish the diagnosis and monitor therapy and the emergence of complications, thus the progress of the disease can be monitored. Examination of blood glucose levels during or ad random can measure blood glucose levels without measuring the time of the last meal. The puskesmas has a Chronic Disease Control Program (PROLANIS) which aims to encourage participants with chronic illness to achieve optimal quality of life. PROLANIS is held every month by giving drugs and blood glucose checks when, in trimester I prolanis patients high sugar levels should be decreased in trimester II. Objective to find out the description of blood glucose levels when in trimester I and trimester prolanis patients in Banyumas Wangon II Health Center in 2019. Research Methods this study was an observational study with descriptive research criteria with a sample of all PROLANIS patients who examined blood glucose levels. Results the study subjects were 45 PROLANIS patients who were examined for blood glucose levels at the time. The results showed that 6 patients were male (41.31\%) and 39 patients were female (58.69\%) Conclusion this study shows the results of glucose levels in PROLANIS patients the highest male sex in trimester I was 901 and trimester II was 657, the highest blood glucose level in I trimester I was 1372 and trimester II 841.
\end{abstract}


Compliance with this treatment remained a decline main measure in the process of changing blood glucose levels.

Keywords: Blood Glucose While, Prolanis, Trimester I and Trimester II

\section{Pendahuluan}

Diagnosis parameter kadar glukosa pada instansi laboratorium klinik adalah salah satu parameter pemeriksaan yang sangat bayak dilakukan. Sebagai paremeter pemeriksaan untuk mendiagnosis penyakit Diabetes Mellitus (DM) maka pemeriksaan glukosa darah digunakan sebagai penegak diagnosis dan untuk memonitoring terapi dan timbulnya komplikasi, sehingga terjadinya perkembangan penyakit dapat dimonitoring dengan baik (Kardika,2013). Pemeriksaan kadar glukosa darah sewaktu atau ad random dapat digunakan untuk mengukur kadar glukosa darah tanpa mengukur waktu makan terakhir (Sacher,2014). Istilah pada tingkat glukosa dalam darah disebut sebagai kadar glukosa. Umumnya kadar glukosa dalam darah yaotu 70-150 mg/dl karena dalam tubuh kadar glukosa pada serum diatur dengan ketat, dan kadar glukosa mengalami peningkatan pada waktu setelah makan dan kadar terendah ditemukan pada waktu pagi hari sebelum makan (Henrikson,2009). Pada Puskesmas dikenal adanya suatu program PROLANIS (Program Pengendalian Penyakit Kronis) yang bersinergi dengan BPJS (Badan Penyelenggaraan Jaminan Sosial) pada area fasilitas kesehatan (faskes) pertama yang melakukan kerjasama dengan BPJS kesehatan serta adanya kebijakan dari Kepala Puskesmas. Program PROLANIS bertujuan untuk mendorong masyarakat dengan status penyandang penyakit kronis untuk mencapai kualitas hidup optimal, dengan peserta terdaftar yang berkunjung ke fasilitas tingkat pertama memberikan hasil baik terhadap pemeriksaan spesifik khusus penyakit DM sesuai panduan klinis, sehingga bisa digunakan dalam pencegahan terjadinya penyakit komplikasi. Adapun untuk sasaran pada program PROLANIS yaitu semua peserta yang terdaftar pada BPJS Kesehatan. Beberapa kegiatan yang ada pada program PROLANIS yaitu aktifitas edukasi/konsultasi medis, kunjungan rumah (home visit), pengingat (reminder), kelompk (aktivitas klub), serta untuk memantau status kesehatan. Penderita DM pada pembangunan kesehatan untuk Indonesia yang lebih sehat mempunyai tujuan agar meningkatnya SDM kesehatan yang merata dan bermutu serta manajemen kesehatan yang akuntabel, transparan berdayaguna dan berhasilguna untuk menetapkan desentralisasi kesehatan yang bertanggungjawab, meningkatnya pemberdayaan masyarakat, dalam pembangunan kesehatan melalui kerjasama nasional dan global serta meningkatnya pelayanan kesehatan yang merata, terjangkau, bermutu, dan berkeadilan, ditandai oleh masyarakatnya yang hidup sehat yang mandiri dan berkeadilan sesuai dengan visi dari Departemen Kesehatan (Depkes RI, 2009).

World Health Organisation (WHO) atau lembaga kesehatan dunia menyebutkan bahwa prevalensi penderita DM di Indonesia bisa terjadi kenaikan drastis yaitu pada tahun 2000 sebanyak 8,4 jt penderita menjadi 21,3 jt penderita pada tahun 2030 nanti. Peningkatan penderita ini dapat terjadi bila negara tidak serius dan fokus dalam penanaganan kasus DM seperti upaya pencegahan, penanganan dan kepatuhan dalam pengobatan penyakit. Pada tahun 2006 di Asia Tenggara tercatat sebanyak lebih dari 50 juta orang penderita DM (Trisnawati, 2013). Prolanis pada umumnya pada orang lanjut usia, dan biasa menderita penyakit tidak menular seperti hipertensi, DM, jantung dll. Orang lanjut secara umum mengalami penyempitan pembuluh darah sehingga memicu terjadinya penyakit hipertensi dan penyakit komplikasi lainyya pada organ ginjal, jantung, dan sebagainya sehingga terjadi penyakit tidak menular lainnya (Sartika, 2020).

Trimester berasal dari kata "trimestris" yang berarti tri (tiga) dan mensis (bulan). Trimester secara teknis didefinisikan sebagai periode 3 bulan yang berhubungan dengan siklus. Berdasarkan data tahunan di Wilayah Kerja Puskesmas Wangon II pada tahun 2018 ditemukan kasus DM sebanyak 400 orang dan tahun 2019 sebanyak 362 orang, sedangkan penderita DM yang mengikuti prolanis di Puskesmas Wangon II berjumlah 45 orang. 


\section{Metode}

Jenis penelitian yang digunakan dalam penelitian ini deskriptif dengan pendekatan observasi. Populasi dalam penelitian ini adalah 45 pasien prolanis di Puskesmas Wangon II Banyumas. Subjek penelitian ini adalah peserta PROLANIS Puskesmas Wangon II, dengan menggunkaan data data sekunder. Data sekunder merupakan data yang didapatkan dari hasil pemeriksaan glukosa darah pada pasien prolanis trimester I dan trimester II menggunakan darah kapiler dengan test strip di laboratorium puskesmas wangon II dengan metode non enzimatik menggunakan alat POCT glucose (NESCO).

\section{Hasil dan Pembahasan}

Penelitian ini dilakukan dengan pengambilan data pasien prolanis selama bulan Januari-Juni 2019 yang berjumlah 45 orang yang terdiri dari 6 pasien laki-laki dan 39 pasien perempuan. Distribusi frekuensi kadar glukosa darah sewaktu pada pasien prolanis trimester I dan trimester II Di Puskesmas Wangon II Banyumas Tahun 2019 dapat dilihat pada tabel 1 sebagai berikut :

Tabel 1 Gambaran Kadar Glukosa Darah Sewaktu pada Pasien Prolanis Trimester I dan Trimester II di Puskesmas Wangon II Banyumas Tahun 2019

\begin{tabular}{ccccc}
\hline $\begin{array}{c}\text { Jenis } \\
\text { Kelamin }\end{array}$ & $\begin{array}{c}\text { Trimester } \\
\text { I }\end{array}$ & $\begin{array}{c}\text { Trimester } \\
\text { II }\end{array}$ & Jumlah & \% \\
\hline Laki-laki & 901 & 657 & 6 & 41.31 \\
Perempuan & 1372 & 841 & 39 & 58.69 \\
\hline Jumlah & 2.273 & 1498 & 45 & 100 \\
\hline
\end{tabular}

Tabel 1 menunjukkan bahwa dari 45 pasien prolanis yang melakukan pemeriksaan glukosa darah berjenis kelamin laki-laki 6 pasien $(41.31 \%)$ dan perempuan 39 pasien $(58.69 \%)$. Hal ini dapat disimpulkan bahwa pasien prolanis tertinggi dalam melakukan pemeriksaan glukosa adalah pasien perempuan yaitu sebanyak 39 orang.

Glukosa adalah salah satu dari jenis karbohidrat yang merupakan sumber tenaga. Selain dari pada itu, glukosa juga berfungsi sebagai molekul utama dalam pembentukan energi pada tubuh terutama untuk kerja otak dan sel darah merah. Sumber glukosa ini berasal dari makanan yang mengandung karbohidrat. Hasil penelitian yang dilakukan pada PROLANIS di Puskesmas Somagede Kabupaten Banyumas menunjukkan bahwa dari 35 responden terdapat 8 pasien dengan kadar glukosa darah tinggi, 3 pasien dengan kadar glukosa darah normal, dan sisanya 24 pasien dengan kadar glukosa rendah (Ashary, 2019). Sedangkan hasil penelitian pada PROLANIS DM Hipertensi di Klinik Pratama UKSW Salatiga didapatkan bahwa kadar glukosa normal dan melebihi normal ditemukan pada kasus normotensi, prehipertensi, dan hipertensi derajat 1 (Imawati, 2020).

Diabetes Mellitus merupakan penyakit kronis dengan kategori serius karena penyakit ini menyebabkan pankreas yang memproduksi insulin yang tidak cukup untuk memenuhi kebutuhan tubuh. DM ini ditandai dengan tingginya kadar glukosa dalam darah (Hiperglikemia) (Khoirin \& Hartono, 2021). Diabetes mellitus tipe 2 (DM Tipe 2) adalah penyakit metabolik dengan gelaja terjadinya hiperglikemi karena terjadinya kegagalan sekresi insulin, ataupun kerja insulin maupun keduanya 
(Gunardi, 2020). Pada pasien DM dengan kejadian hiperglikemia kronis akan mengakibatkan terjadinya lingkungan hipoksia di interstitium ginjal, terjadinya disfungsi ginjal ini akan berdampak pada Glomelurus Filtration Rate (GFR). Hasil riset menunjukkan bahwa penyakit DM tipe 2 dapat mengalami tingkat anemia sedang (Khoirin \& Hartono, 2021).

\section{Simpulan dan Saran}

\section{Simpulan}

Berdasarkan analisis data yang dilakukan maka dapat disimpulkan bahwa dari 45 pasien prolanis terdiri dari pasien yang berjenis kelamin laki-laki berjumlah 6 orang dan perempuan 39 orang. Kadar glukosa darah tertinggi pasien laki-laki pada trimester I adalah sebesar $340 \mathrm{mg} / \mathrm{dl}$ dan pada trimester II adalah sebesar $240 \mathrm{mg} / \mathrm{dl}$, sedangkan kadar glukosa terendah pada trimester I adalah $120 \mathrm{mg} / \mathrm{dl}$ dan trimester II adalah $135 \mathrm{mg} / \mathrm{dl}$. Untuk pasien perempuan, kadar glukosa tertinggi pada trimester I adalah $458 \mathrm{mg} / \mathrm{dl}$ dan trimester II adalah $256 \mathrm{mg} / \mathrm{dl}$, sedangkan kadar glukosa terendah pada trimester I adalah $80 \mathrm{mg} / \mathrm{dl}$ dan trimester II adalah $109 \mathrm{mg} / \mathrm{dl}$. Kadar glukosa darah sewaktu pada pasien prolanis dengan prevalensi terbanyak adalah pasien berjenis kelamin perempuan, kadar glukosa pada pasien perempuan di trimester I adalah 1372 dan trimester II adalah 841 (58.69\%) sedangkan pada pasien laki-laki trimester I adalah 901 dan trimester II adalah 675 (41.31\%).

\section{Saran}

Bagi responden, hendaknya responden ruitn untuk memonitoring kadar glukosa darahnya secara teratur. Diharapkan peserta PROLANIS dapat memberikan laporan pada petugas puskesmas terkait kadar glukosanya dan terkait edukasi maupun diet PROLANIS, diharapkan juga kepada responden untuk memberikan laporan pada pihak puskesmas jika tidak dilakukan home visit. Diharapkan responden bisa mengikuti senam, rutin melakukan pemeriksaan kesehatan, dan melakukan pengobatan secara rutin.

Bagi Puskesmas, adanya hasil penelitian ini diharapkan puskesmas dapat melakukan kegiatan PROLANIS secara berkesinambungan, dan dilakukan sesuai dengan program pemerintah.

\section{Daftar Pustaka}

Ashary, K. L. (2019). Kadar Glukosa Darah dan Tekanan Darah pada Anggota PROLANIS di Puskesmas Somagede Kabupaten Banyumas. Jaringan Laboratorium Medis, 1(2), 91-97.

Alwi, I. (2014). Panduan Klinis Hipertensi BPJS Kesehatan. Jakarta: Badan Penyelenggaraan Jaminan Sosial (BPJS) Kesehatan.

Depkes RI. (2009). Sistem Kesehatan Nasional. Jakarta.

Gandasoebrata. (2007). Penuntun Laboratorium Klinik. Jakarta: Dian Rakyat.

Gunardi. (2020). Profil HbA1c , Kolesterol dan Trigliserida pada Pasien Diabetes Mellitus Tipe 2 Profile of HbAlc , Cholesterol and Triglyceride in Type 2 Diabetes Mellitus. Jaringan Laboratorium Medis, 02(02), 89-93

Henrikson J.E. (2009). Blood Glucose Levels. Philadelphia Baltomore New York: Wolters Kluwer Health

Irawan, M.A. (2007). Cairan Tubuh. Elektrolit, dan Mineral. Polton Sports Science and Perfomace Lab. Avaible from: www.pssplab.com/journal/01.pdf

Imawati, H. (2020). Gambaran Kadar Glukosa , Tekanan Darah, dan Profil Lipid pada Pasien Prolanis DM Hipertensi. Jaringan Laboratorium Medis, 02(02), 61-67.

Khoirin, W. A., \& Hartono, R. (2021). Kadar Hemoglobin pada Pasien Diabetes Mellitus Tipe 2. Jurnal Laboratorium Medis, 03(01), 23-28.

Maulana, H. D. J. (2009). Promosi Kesehatan. Jakarta: EGC. 
Maryunani, Anik NS. (2008). Buku saku diabetes pada kehamilan. Jakarta: Trans Info Media;2008.

Nabyl. E. A. (2012). Panduan hidup sehat: mencegah dan mengobati Diabetes Mellitus. Yogyakarta: Aulia Publising.

Peraturan Mentri Kesehatan Nomor 75 Tahun 2014. Tentang Pusat Kesehatan Masyarakat. 2014.

Raraswati. Anjar. (2018). Peran Program Prolanis Dalam Penurunan Kadar Gula Darah Puasa Pada Pasien Diabetes Melitus Tipe 2 di Puskesmas Kecamatan Jatinagor.

Sacher, R A. (2004). Tinjauan Klinis Hasil Pemeriksaan Laboratorium. Jakarta : EGC

Shahab. (2006). Diagnosis dan Penatalaksanaan Diabetes Mellitus (disarikan dari konsesus pengelolaan Diabetes Mellitus di Indonesia, Perkeni,2006.

Sartika, D. (2020). Gambaran Sedimen Urin pada Orang Lanjut Usia yang Mengalami Hipertensi. Jaringan Laboratorium Medis, 02(02), 94-96.

Trisnawati, S.K. \& Setyogoro, S. (2013). Faktor resiko kejadian Deabetes Mellitus tipe 2 di Puskesmas Kecamatan Cengkareng. Jakarta Barat tahun 2012. Jurnal Ilmiah Kesehatan, 5(1). 